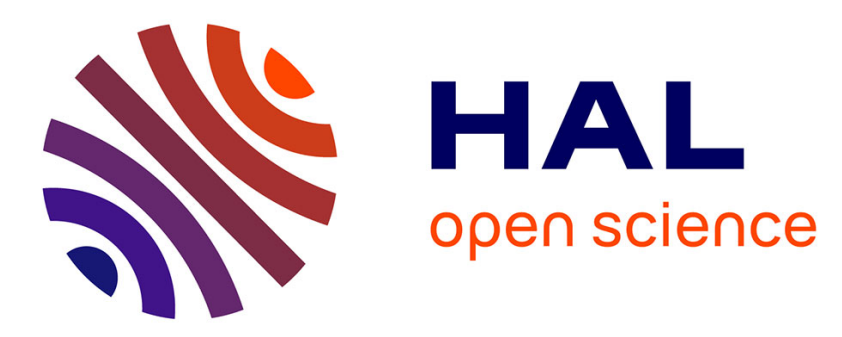

\title{
Effects of climate and land use on the occurrence of viruliferous aphids and the epidemiology of barley yellow dwarf disease
}

Frederic Fabre, Manuel Plantegenest, Lucie Mieuzet, Charles-Antoine Dedryver, J.L. Leterrier, Emmanuel Jacquot

\section{To cite this version:}

Frederic Fabre, Manuel Plantegenest, Lucie Mieuzet, Charles-Antoine Dedryver, J.L. Leterrier, et al.. Effects of climate and land use on the occurrence of viruliferous aphids and the epidemiology of barley yellow dwarf disease. Agriculture, Ecosystems and Environment, 2005, 106 (1), pp.49-55. 10.1016/j.agee.2004.07.004 . hal-02682393

\section{HAL Id: hal-02682393 \\ https://hal.inrae.fr/hal-02682393}

Submitted on 1 Jun 2020

HAL is a multi-disciplinary open access archive for the deposit and dissemination of scientific research documents, whether they are published or not. The documents may come from teaching and research institutions in France or abroad, or from public or private research centers.
L'archive ouverte pluridisciplinaire HAL, est destinée au dépôt et à la diffusion de documents scientifiques de niveau recherche, publiés ou non, émanant des établissements d'enseignement et de recherche français ou étrangers, des laboratoires publics ou privés. 
Version définitive du manuscrit publié dans / Final version of the manuscript published in :

Agriculture Ecosystems and Environment, 2005, vol.106, no.1, 49-55

\title{
Effects of climate and land-use on the occurrence of viruliferous aphids and the epidemiology of barley yellow dwarf disease.
}

\author{
Frédéric Fabre ${ }^{\mathrm{a}, \mathrm{b}}$, Manuel Plantegenest ${ }^{\mathrm{a}}$, Lucie Mieuzet $^{\mathrm{a}}$, Charles A. Dedryver ${ }^{\mathrm{a}}$, Jean-Luc \\ Leterrier $^{\mathrm{b}}$, Emmanuel Jacquot ${ }^{\mathrm{a}, *}$.
}

aINRA/Agrocampus Rennes, Unité Mixte de Recherche Biologie des Organismes et des Populations appliquée à la Protection des Plantes (BiO3P), Domaine de la Motte B.P. 35327, F-35653 Le Rheu cedex, France.

${ }^{b}$ Bayer CropScience France, 16 rue Jean-Marie Leclair 69009 Lyon, France

*Corresponding author. Tel.: +332234858 17; Fax: + 33223485150 .

Email address: jacquot@rennes.inra.fr

\begin{abstract}
Fabre F., Plantegenest M., Mieuzet L., Dedryver C. A., Leterrier J. L. \& Jacquot E. 2005. Effects of climate and land-use on the occurrence of viruliferous aphids and the epidemiology of barley yellow dwarf disease. Agriculture, Ecosystems \& Environment, 106, 49-55.

Barley Yellow Dwarf (BYD) disease is one of the most severe viral diseases in autumn sown cereals. In western Europe, crop losses are mainly due to the PAV species of BYD viruses transmitted by Rhopalosiphum padi, the most abundant aphid in autumn. The proportion of migrant winged aphids that carry viruses in autumn is considered a major epidemiological factor for determining the disease incidence. In the main French cereal areas, during a 6 week period in autumn 1999 to 2002, the proportion of viruliferous R. padi assessed using a TAS-ELISA technique was on average of $4.98 \%$ (range 2.01-9.91 \%). Variations according to trap location were correlated with land-use at the regional scale, annual variations being correlated with the climate of the year. Implementations of these results to improve BYD disease management program are discussed.
\end{abstract}




\section{Keywords}

Integrated pest management, landscape ecology, Rhopalosiphum padi, viruliferous aphids, virus epidemiology, TAS ELISA. 


\section{Introduction}

Landscape ecology is a fast growing scientific field expected to provide tools to manage agroecosystems in terms of sustainable crop protection (Estevez et al., 2000) and to provide information on ecological processes such as the annual occurrence of a plant disease. Understanding the relationships between the spatially heterogeneous environment and recurring patterns of crops injury may help to design new strategies for plant disease management, yet few studies (Nelson et al., 1994; Barnes et al., 1999) have dealt with how landscape characteristics could affect plant disease epidemiology.

Barley yellow dwarf (BYD) disease, one of the world's most severe viral diseases of autumn sown cereal, is caused by members of the Luteoviridae family. BYD viruses are transmitted in a persistent, circulative, non-propagative manner by several aphid species (Irwin and Thresh, 1990). Three aphids species are the main vectors in most of Europe: Rhopalosiphum padi L., Sitobion avenae Fabricius and Metopolophium dirhodum Walker (Plumb, 1995). The virus host plants (Poaceae) are important components of agricultural landscapes both as cultivated crops (e.g. wheat, barley, maize, oats, pasture grasses) or as volunteer, spontaneous species in non-cultivated areas. Only perennial species can be reservoirs of viruses and vectors during the whole year. To complete its life cycle, viral inoculum has to 'jump' several times within an agricultural landscape, from senescent to alternative hosts (the bridging crops; Irwin and Thresh, 1990). In temperate climates, maize (Henry and Dedryver, 1989; Irwin and Thresh, 1990), cereal volunteers (Henry et al., 1993; Masterman et al., 1994; Plumb, 1995) and some pastures grasses (Henry and Dedryver, 1991) are important to carry over BYD viruses through summer, spontaneous grasses being of lesser importance (Irwin and Thresh, 1990).

Yield losses to barley and wheat are mainly due to autumn infections (Carrigan et al., 1981) caused in $90 \%$ of the cases by R. padi carrying the PAV (padi-avenae virus) (LeclercqLe Quillec et al., 1995) and/or occasionally the MAV (Macrosiphum avenae virus) species of BYD viruses. Environmental conditions govern the pattern and timing of infection by winged viruliferous vectors (primary infection) and the speed of virus dissemination within a field by apterous aphids (secondary spread). Temperature influences both the population dynamics of the vectors $\left(5^{\circ} \mathrm{C}\right.$ is considered to be the developmental threshold for $R$. padi [Elliott and Kieckhefer, 1989], $15^{\circ} \mathrm{C}$ the take-off threshold for alate aphids [Walters and Dixon, 1984]), and the virus transmission process (Lowles et al., 1996). In autumn and winter, some R. padi genotypes enter a phase of sexual reproduction and produce males and gynoparae females when other $R$. padi genotypes continue to reproduce parthenogenetically (Simon et al., 2002) and contribute to spread BYD viruses. 
BYD being controlled by insecticides, decision making tools could help farmers to spray only when necessary. Plumb (1990) observed that the proportion of infective aphids must be taken into account. This proportion can be evaluated by the proportion of viruliferous aphids using ELISA (Burgess et al., 1999). The aims of this study were (i) to collect standardised information on variability in space and time of the proportion of viruliferous $R$. padi during autumn flights and (ii) to look for factors that could account for this variability, based on aphids caught in the French suction traps network.

\section{Materials and methods}

The French AGRAPHID network is a pluri-local suction trap network recording the daily flight activity of winged aphids. Aphids are trapped continuously, collected into bottles filled with 98\% water and $2 \%$ glycerol, and put daily in absolute alcohol until used. The traps are similar to the Rothamsted Insect Survey traps (Macaulay et al., 1988), and aphids caught are considered to be representative of the flights within $32 \mathrm{~km}$ (Robert and Gamon, 1989) and up to $80 \mathrm{~km}$ (Taylor, 1973). A total of 4607 females R. padi caught from October 1 to November 7 (standard weeks 40 to 45), at $12.2 \mathrm{~m}$ height in four traps and during four years (1999 to 2002) was analysed. Traps were situated at Loos-en-Gohelle (near Lens, Pas de Calais department), La Neuvillette (near Reims, Marne department), Fleury-les-Aubrais (near Orléans, Loiret department) and Le Rheu (near Rennes, Ille-et-Vilaine department) close to the most important French small grain production areas (Fig. 1), French departments being broadly equivalent to level 3 statistical territorial unit (NUTS 3, Eurostat). A maximum of 100 aphids per week, trap and year was considered.

Aphids were analysed individually the week after trapping using ELISA. Each aphid was placed in a microcentrifuge tube, ground with a pestle in $100 \mu \mathrm{l}$ of grinding buffer (Phosphate buffer saline (PBS), $0.05 \%$ (v/v) Tween 20 and $2 \%(\mathrm{w} / \mathrm{v})$ polyvinylpyrrolidone [PVP K40, Sigma]), and immediately used for ELISA tests. The detection of BYDV-PAV and BYDV-MAV was performed using a triple antibody sandwich (TAS) assay. Microtitre plates were coated with $1 \mu \mathrm{g} / \mathrm{ml}$ BYDV-polyclonal PAV52 antibody (supplied by H. Lapierre, INRA Versailles, France) in carbonate buffer ( $\mathrm{pH} \mathrm{9.6)} \mathrm{for} \mathrm{two} \mathrm{hours} \mathrm{at} 37^{\circ} \mathrm{C}$. Between each step of the ELISA protocol, plates were washed three times with PBST buffer (PBS, $0.05 \%(\mathrm{v} / \mathrm{v})$ Tween 20). Samples (50 $\mu \mathrm{l}$ of ground aphid) were added to coated wells and left overnight at $4^{\circ} \mathrm{C}$. A mouse-derived monoclonal antibody PM63 raised against PAV and MAV isolates (supplied by H. Lapierre, INRA Versailles, France) was diluted 1:10 in grinding buffer and 50 $\mu \mathrm{l}$ aliquots were added to the plate wells and incubated for two hours at $37^{\circ} \mathrm{C}$. Alkaline phosphatase conjugated to anti-mouse antibody [Sigma] diluted 1:10000 with grinding buffer 
supplemented with $0.2 \%(\mathrm{w} / \mathrm{v})$ ovalbumin, was added to wells. After two hours at $37^{\circ} \mathrm{C}$, wells were filled with $50 \mu \mathrm{l}$ p-nitrophenyl phosphate $(1 \mathrm{mg} / \mathrm{ml})$ in substrate buffer $(1 \mathrm{~N}$ diethanolamine, $\mathrm{pH}$ 9.6). The colorimetric reaction was allowed to proceed for two hours at room temperature. Absorbance of samples was read at $405 \mathrm{~nm}$ (A405) using a microplate reader (Titertek Multiscan [MCC]). Samples were considered as containing virus particles when A405>0.1. Individuals of the Rp1 clone of $R$. padi (Simon et al., 1991), an efficient vector for BYDV-PAV transmission (Sadeghi et al., 1997a), were reared in a controlled chamber at $20^{\circ} \mathrm{C}, 16: 8 \mathrm{~L} / \mathrm{D}$ cycle on healthy barley seedlings (cv. Express) and on BYDVPAVb infected plants (Papura et al., 2002) and used as negative and positive reference controls respectively for TAS ELISA.

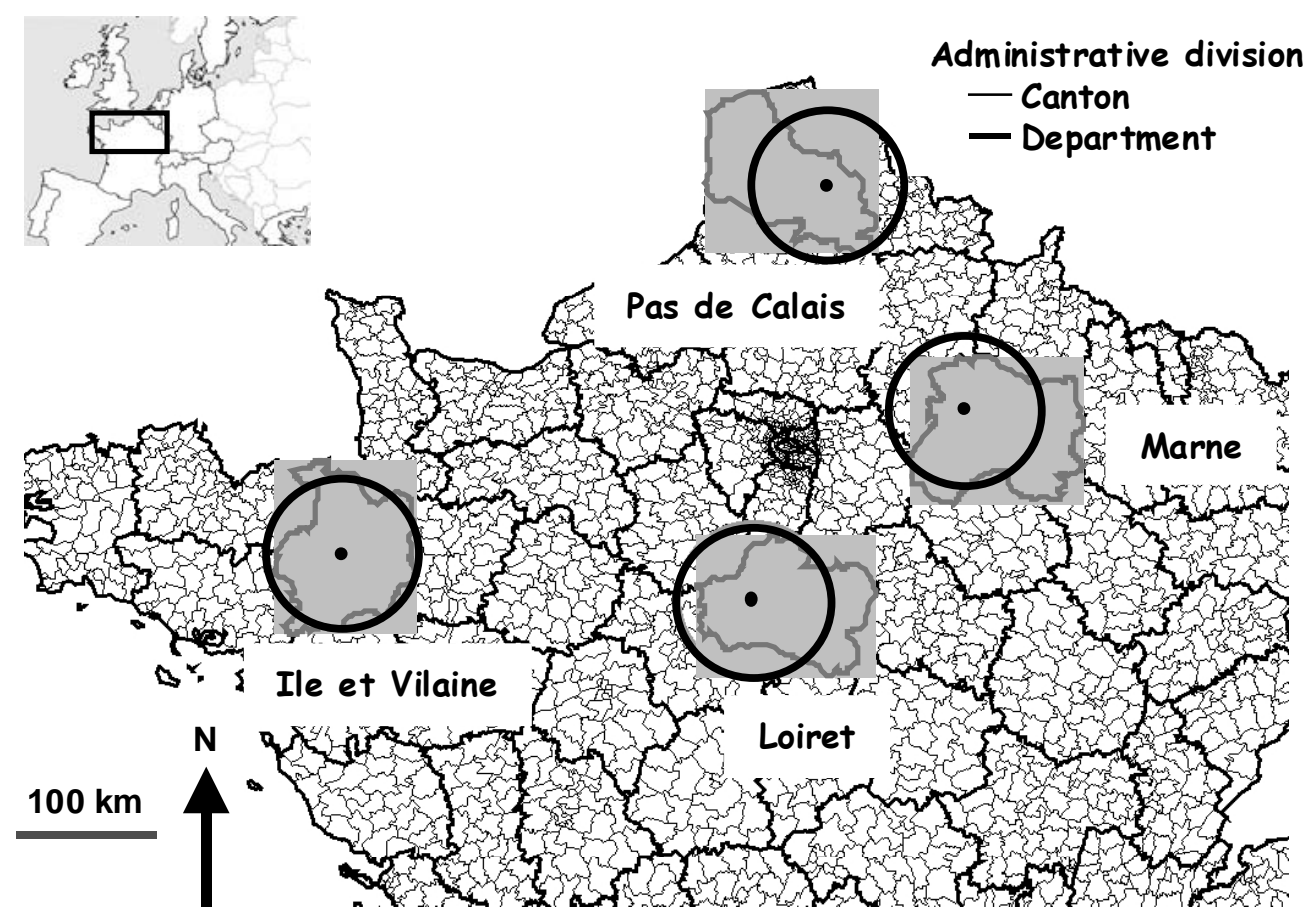

Figure 1. Map showing the four French departments $(\square)$ where suction traps $(\bullet)$ were located: Rennes (Ille-et-Vilaine), Orléans (Loiret), Reims (Marne) and Lens (Pasde-Calais) with a $50 \mathrm{~km}$ radius around each location. 


\section{Data analysis}

The proportion of viruliferous aphids was calculated per week, year and suction trap according to the results of the TAS-ELISA. Data were analysed using a generalised linear model assuming a binomial distribution and a logit link function (McCullagh and Nelder, 1989) with S-Plus 2000 (Math Soft, Seattle, WA).

The effects of 'Year' (1999, 2000, 2001, 2002), 'Week' (standard weeks 40 to 45) and 'Trap' (Lens, Orléans, Reims and Rennes) and of their interactions were considered first. A stepwise model selection was performed using Akaike's Information Criterion (AIC) to identify the significant factors. A chi-square test was performed to assess the level of significance of the selected factors. Finally, pairwise comparisons of the percentages of viruliferous aphids according to the levels of the selected factors were carried out using a contrast test with SAS Software (vers. 8, SAS Inc., Cary, NC).

A variable 'Temp' defined as day-degree accumulation above $5^{\circ} \mathrm{C}$ from January to August was calculated in each of the four locations using data collected from Météo France network station in standard conditions ( $2 \mathrm{~m}$ high under shelter) and a similar generalised linear model with two factors, 'Temp' and 'Trap' and their interaction was fitted to the data.

The effect of the ratio between the area of land sown to wheat, barley and oats and the area of land sown to maize in each of the four departments was included based on the data of the French Ministry of Agriculture (Anonymous, 2003). The effect of this ratio was tested using a generalised linear model with 2 factors, 'Ratio' and 'Year' and their interaction.

\section{Results}

As expected, R. padi was the most abundant aphid species with total numbers of females per trap and year ranging from 210 to 1122 (436 on average). For the same period, numbers of the other two main vectors remained low, S. avenae ranging from 3 to 19 in Rennes and from 1 to 3 in Lens, M. dirhodum from 1 to 9 in Rennes and from 2 to 5 in Lens. $R$. padi flight was highly variable between years and traps and generally increased through September to peak in the second week of October, few aphids being recorded after November 7. The number of aphids tested per year and trap ranged from 168 to 495 (mean=307), representing $70 \%$ of trapped individuals.

The effect of the factors 'Year' ( $d f=3$, Deviance=22.08, $\left.P<10^{-4}\right)$ and 'Trap' $(d f=3$, Deviance $=12.54, \mathrm{P}=5.10^{-3}$ ) were highly significant, and the proportion of viruliferous aphids per year and trap ranged from $2.01 \%$ to $9.91 \%$ (Fig. $2 A$ ), mean value $=4.98 \%$ (SD 2.27, 
$\mathrm{n}=15)$. The proportion of viruliferous $R$. padi was significantly higher in 1999 and 2002 than in 2000 and 2001 (Fig. 2B), and significantly higher in Lens and Reims than in Rennes, Orléans being intermediate (Fig. 2C).

The analysis indicated that the factors 'Trap' and 'Temp' were highly significant (Table 1 ), but not their interaction. Fluctuations of the proportion of viruliferous aphids matched the variations in the annual day-degree accumulation above $5^{\circ} \mathrm{C}$ during the first eight months of the year (Fig. 2B).

Table 1 : Analysis of deviance (generalised linear model analysis) with two factors, trap location ('Trap'), the day-degree accumulation above $5^{\circ} \mathrm{C}$ ('Temp') and their interaction.

\begin{tabular}{llllll}
\hline \hline & Df & Deviance & Df res & Deviance res. & P(Chi) \\
\hline Null & & & 14 & 40.25 & \\
Trap & 3 & 14.94 & 11 & 25.31 & 0.0019 \\
Temp & 1 & 10.83 & 10 & 14.48 & 0.001 \\
Trap* Temp & 3 & 3.81 & 7 & 10.67 & 0.28 \\
\hline
\end{tabular}

Assessing the ratio between the area sown to small grain and that sown to maize at the department level (level NUTS 3) or within a $50 \mathrm{~km}$ radius around the suction trap location did not produce any significant difference. The department was therefore an adequate surface unit for assessing crop areas. The proportions of land sown to wheat, barley, oats or maize remained rather constant both over the years and across the areas (34\% for Rennes, Orléans and Reims and $37 \%$ for Lens). Although the ratio between the surface of land sown to small grain (wheat, barley and oats) relative to that sown to maize showed rather small variations within an area between years it exhibited large differences between areas (1:1 in Rennes, 5:1 in Orléans and Lens, 10:1 in Reims). The analysis indicated that the factors 'Year' and 'Ratio' had a highly significant effect on the proportion of viruliferous aphids sampled (Table 2), but not their interaction. Fluctuations of the proportions of viruliferous aphids matched the variations in the ratio of land sown to small grain cereals (wheat, barley and oats) compared to that sown to maize (Fig. 2C). 
Table 2 : Analysis of deviance (generalised linear model analysis) with two factors, 'Year' and 'Ratio' (area sown to wheat, barley and oats vs. area sown to maize) and their interaction.

\begin{tabular}{llllll}
\hline \hline & Df & Deviance & Df res & Deviance res. & P(Chi) \\
\hline Null & & & 14 & 40.25 & \\
Year & 3 & 22.08 & 11 & 18.15 & $6.10^{-5}$ \\
Ratio & 1 & 9.88 & 10 & 8.27 & 0.0016 \\
Year*Ratio & 3 & 0.64 & 7 & 7.63 & 0.89 \\
\hline
\end{tabular}

A

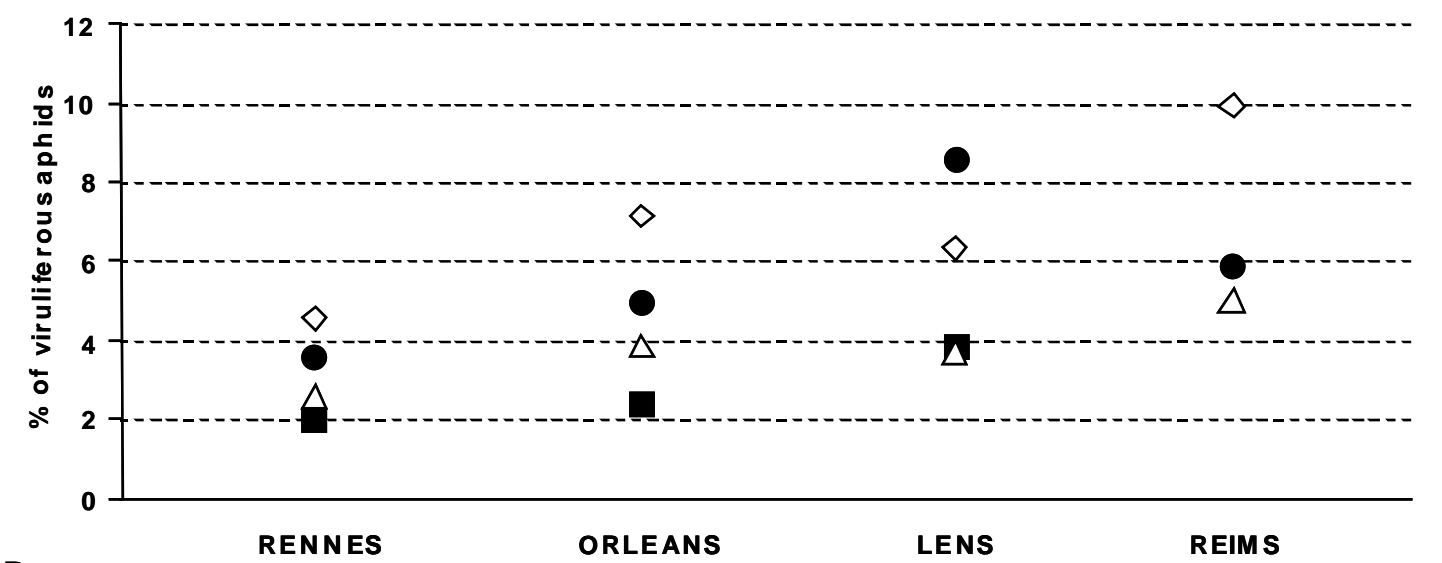

B

REN NES

C
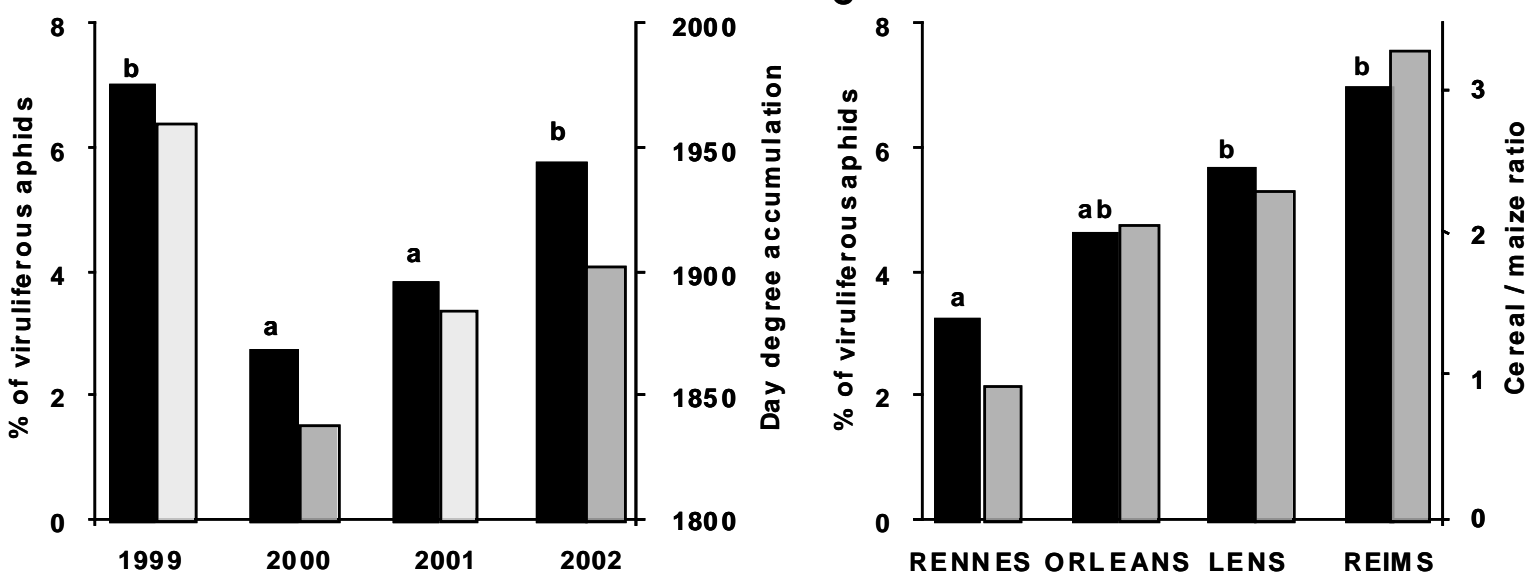

Figure 2. Effect of year, trap location, day degree accumulation and crop ratio on the percentage of viruliferous $R$. padi. A: Percentage of viruliferous $R$. padi per trap and year ( $(: 1999, \mathbf{\square}: 2000, \Delta: 2001, \bullet: 2002)$. B: Average proportions of viruliferous $R$. padi $(\square)$ and annual sum of day degree accumulation above $5^{\circ} \mathrm{C}(\square)$ from January to August (average of four locations). C: Average proportion of viruliferous $R$. padi per trap ( $\boldsymbol{\square})$ and square root of ratio area sown to small grain cereals vs. area sown to maize ( $\square$ ) (mean of 4 years) (same letter within a graph are not significantly different). 


\section{Discussion}

The TAS-ELISA technique adopted here for the detection of viruliferous aphids instead of infectivity assays requiring live aphids, or nucleic acid based assays proved a suitable method for the routine screening of large sample sizes at an acceptable cost (French, 1995).

The average proportion of viruliferous aphids remained rather low, but varied significantly both in space and time (SD 2.27, $\mathrm{n=15}$ ) and was consistent with observations in the U.K. (Plumb et al., 1986; McGrath and Bale, 1989) or in U.S.A. (Halbert et al., 1992), slightly higher proportions being recorded by Foster et al. (1993) in Rothamsted (U.K.) and Leclercq-Le Quillec et al. (1995) in Rennes. These authors used in vivo infectivity assay to assess the percentage of infective aphids caught at $1.5 \mathrm{~m}$. The proportion of viruliferous aphids may be lower for aphids trapped at $12.2 \mathrm{~m}$ than at $1.5 \mathrm{~m}$ (Burgess et al., 1999) and ELISA technique could well lead to an overestimate because of its limited sensibility (Fabre et al., 2003). On the contrary, some viruliferous aphids could failed to transmit the virus in biological assays. Sadeghi et al. (1997a) found no important variation in the transmission capacity of $R$. padi clones whereas Guo et al. (1996) identified a poorly PAV transmitting clone of the same species. A high variability in the transmission efficiency of $R$. padi was detected for BYDV-MAV (Sadeghi et al., 1997b), which is less common in autumn. For all those reasons, direct comparisons between estimates provided by ELISA and in vivo assays could be hazardous.

Both gynoparae and virginiparae $R$. padi were used in the present study, which can not be distinguished morphologically and were assumed to be similar in the proportion of viruliferous aphids. The proportion of the two morphs showed large geographical variations in France according to winter harshness (Rispe et al., 1998).

The large spatio-temporal scale used in the present study allowed to demonstrate both a regional and a year effect on the proportion of viruliferous aphids in northern France. The numbers of viruliferous aphids were always lower in Rennes than in Lens and lower in 2001 than in 1999.

The warmer the January to August period, the higher was the proportion of viruliferous aphids in the following autumn, perhaps due to an increased rate of population growth and, consequently, of virus spreading in the agroecosystem leading to a higher percentage of viruliferous aphids in autumn. The proportion of viruliferous aphids also increased with the ratio of the area sown to small grain compared to maize, which could account for the regional pattern observed. Both volunteer small grains and maize are considered to be major bridging crops providing good reservoirs of aphids vectors. Maize, 
however, seems to sustain smaller virus concentrations than wheat, barley and oats (Hammond et al., 1983; Plumb, 1990), and is probably a poorer source for virus acquisition. The virus titer in plants is known to alter the probability of a vector acquiring and transmitting the disease (Irwin and Thresh, 1990). Small grains volunteer can potentially reach a higher proportion of infected plants than maize, in which BYD viruses infection is only efficient between the 2- and the 10-12-leaves growth stage (Plumb, 1995; Haack et al., 1999).

The management of plant virus disease could benefit from applyingthe principles of landscape ecology (Nelson et al., 1994; Barnes et al., 1999; Estevez et al., 2000; present). Agricultural landscapes that are more or less conducive to infection by BYD viruses therefore ought to be determined with a view to designing more sustainable strategies of crop protection.

\section{Acknowledgements}

We thank Régis Gagneux and Antoine Bily for technical assistance; Danielle Pannetier (INRA Rennes), Anne Marie Chudzicki (SRPV Nord), Sabine Babé (SRPV Champagne Ardenne) and Michelle Aribaud (SRPV Centre) for collecting and determining aphids. We are grateful to Hervé Lecoq (INRA Avignon), Benjamin Raccah (Volcani center, Israel) and Jacques Baudry (INRA Rennes) and to two anonymous referees for critical reading of the manuscript. This work was supported by the Institut National de la Recherche Agronomique (France) and Bayer CropScience, and by the French Région Bretagne (Opération A1C701, Programme 691).

\section{References}

Anonymous, 2003. Statistique agricole annuelle 1989 à 2001 et 2003, Agreste Numérique (CD-ROM), Ministère de l'Agriculture Français.

Barnes, J. M., Trinidad-Correa, R., Orum, T. V., Felix-Gastelum, R., Nelson, M. R., 1999. Landscape ecology as a new infrastructure for improved management of plant viruses and their insect vectors in agroecosystems. Ecosyst. Health 5, 26-35.

Burgess, A. J., Harrington, R., Plumb, R. T., 1999. Barley and cereal yellow dwarf virus epidemiology and control strategies. In: Smith, H. G., Barker, H. (Eds.), The Luteoviridae. CABI publ. Wallingford, UK, pp. 248-261. 
Carrigan, L.L., Ohm, H.W., Foster, J.E., Patterson, F.L., 1981. Response of winter wheat cultivars to barley yellow dwarf virus infection. Crop Sci. 21, 377-380.

Elliott, N. C., Kieckhefer, R. W., 1989. Effects of constant and fluctuating temperatures on immature development and age-specific life tables of Rhopalosiphum padi (L.) (Homoptera: Aphididae). Can. Ent. 121, 131-140.

Estevez, B., Domon, G., Lucas, E., 2000. Use of landscape ecology in agroecosystem diversification towards phytoprotection. Phytoprotection 81, 1-14.

Fabre, F., Kervarrec, C., Mieuzet, L., Riault, G., Vialatte, A., Jacquot, E., 2003. Improvement of Barley yellow dwarf virus-PAV detection in single aphids using a fluorescent real time RT-PCR. J. Virol. Methods 110, 51-60.

Foster, G.N., Holmes, S.J., Bone, S.F., 1993. Ten years' experience of infectivity indexing as a method of predicting the risk of barley yellow dwarf virus outbreaks in autumnsown cereals in the west of Scotland. In: Williams, G. H. (Ed.), Crop Protection in Northern Britain 1993. Scottish Crop Research Institute, Dundee, pp. 97-102.

French, R., 1995. Barley Yellow Dwarf: Diagnostic Procedures and Reagents. In: D'Arcy, C. J., Burnett, P. A. (Eds.), Barley Yellow Dwarf: 40 Years of Progress. American Phytopathological Society, St Paul, pp. 293-306.

Guo, J. Q., Moreau, J. P., Lapierre, H., 1996. Variability among aphid clones of Rhopalosiphum padi L. and Sitobion avenae F. (Homoptera: Aphididae) in transmission of three PAV isolates of barley yellow dwarf viruses. Can. Entomol. 128, 209-217.

Haack, L., Courbon, R., Riault, G., Tanguy, S., Le Vilain, D., Henry, M., Dedryver, C. A., 1999. A plant and field study of BYDV-PAV and -MAV distribution on maize in France. $Z$. Pflanzenkr. Pflanzensch. 106, 297-303.

Halbert, S. E., Connelly, B. J., Bishop, G. W., Blackmer, J. L., 1992. Transmission of barley yellow dwarf virus by field collected aphids (Homoptera: Aphididae) and their relative importance in barley yellow dwarf epidemiology in southwestern Idaho. Ann. Appl. Biol. 121, 105-121.

Hammond, J., Lister, R. M., Foster, J. E., 1983. Purification, identity and some properties of an isolate of barley yellow dwarf virus from Indiana. J. Gen. Virol., 64, 667-676.

Henry, M., Dedryver, C. A., 1989. Fluctuations in cereal aphid populations on maize (Zea mays) in Western France in relation to the epidemiology of barley yellow dwarf virus. J. Appl. Entomol. 107, 401-410. 
Henry, M., Dedryver, C. A., 1991. Occurrence of barley yellow dwarf virus in pastures of western France. Plant Pathol. 40, 93-99.

Henry, M., George, S., Arnold, G. M., Dedryver, C. A., Kendall, D. A., Robert, Y., Smith, B. D., 1993. Occurrence of barley yellow dwarf virus (BYDV) isolates in different habitats in western France and south-west England. Ann. Appl. Biol. 123, 315-329.

Irwin, M. E., Thresh, J. M., 1990. Epidemiology of barley yellow dwarf: a study in ecological complexity. Ann. Rev. Phytopathol. 28, 393-424.

Leclercq-Le Quillec, F., Tanguy, S., Dedryver, C. A., 1995. Aerial flow of barley yellow dwarf viruses and of their vectors in western France. Ann. Appl. Biol. 126, 75-90.

Lowles, A.J., Tatchell, G.M., Harrington, R., Clark, S.J., 1996. The effect of temperature and inoculation access period on the transmission of barley yellow dwarf virus by Rhopalosiphum padi (L.) and Sitobion avenae (F.). Ann. Appl. Biol. 128, 45-53.

Macaulay, E. D. M., Tachell, G. M., Taylor, L. R., 1988. The Rothamsted Insect Survey "12-metre" suction traps. B. Entomol. Res. 78, 121-129.

Masterman, A. J., Holmes, S. J., Foster, G. N., 1994. Transmission of barley yellow dwarf virus by cereal aphids collected from different habitats on cereal farms. Plant Pathol. $43,612-620$.

McCullagh, P., Nelder, J.A., 1989. Generalized Linear Models. Chapman and Hall, London.

McGrath, P. F., Bale, J. S., 1989. Cereal aphids and the infectivity index for barley yellow dwarf virus (BYDV) in northern England. Ann. Appl. Biol. 114,429-442.

Nelson, M. R., Felix-Gastelum, R., Orum, T. V., Stowell, L. J., Myers, D. E., 1994. Geographic information systems and geostatistics in the design and validation of regional plant virus management programs. Phytopathology 94, 898-905.

Papura, D., Jacquot, E., Dedryver, C. A., Luche, S., Riault, G., Bossis, M., Rabilloud, T., 2002. Two-dimensional electrophoresis of proteins discriminates aphid clones of Sitobion avenae differing in BYDV-PAV transmission. Arch. Virol. 147, 1881-1898.

Plumb, R.T., 1990. The epidemiology of barley yellow dwarf in Europe. In: Burnett, P. A. (Ed.), World Perspectives on Barley Yellow Dwarf. CIMMYT, Mexico, pp. 215-227.

Plumb, R.T., 1995. Epidemiology of barley yellow dwarf in Europe. In: D'Arcy, C. J., Burnett, P. A. (Eds.), Barley Yellow Dwarf: 40 Years of Progress. American Phytopathological Society, St Paul, pp. 107-128. 
Plumb, R. T., Lennon, E. A., Gutteridge, R. A., 1986. Barley yellow dwarf virus by monitoring vector populations and infectivity. In: McLean, G. D., Garrett, R. G., Ruesink, W. G. (Eds), Plant Virus Epidemics. Academic press, Sydney, pp. 387-398.

Rispe, C., Hullé, M., Gauthier, J. P., Pierre, J. S., Harrington, R., 1998. Effect of climate on the proportion of males in the autumn flight of the aphid Rhopalosiphum padi L. (Hom., Aphididae). J. Appl. Entomol. 122, 129-136.

Robert, Y., Gamon, A., 1989. Intérêt et limites de l'utilisation des pièges à succion pour l'étude de l'épidémiologie de la jaunisse nanisante de l'orge. In: R. Cavalloro (Ed.), Euraphid Network: Trapping and Aphid Prognosis. Commission of the European Communities, Luxembourg, pp. 213-220.

Sadeghi, E., Dedryver, C. A., Gauthier, J. P., 1997a. Role of acquisition and inoculation time in the expression of clonal variation for BYDV-PAV transmission in the aphid species Rhopalosiphum padi. Plant Pathol. 46, 502-508.

Sadeghi, E., Dedryver, C. A., Riault, G., Gauthier, J. P., 1997b. Variation in transmission of two BYDV-MAV isolates by multiple clones of Rhopalosiphum padi. Eur. J. Plant Pathol. $103,515-519$.

Simon, J.C., Blackman, R.L., Le Gallic, J.F., 1991. Local variability in the life-cycle of the bird cherry-oat aphid Rhopalosiphum padi (L.) in western France. Bull. Entomol. Res. 81, 315-322.

Simon, J. C., Rispe, C., Sunnucks, P., 2002. Ecology and evolution of sex in aphids. Trends Ecol. Evol. 17, 34-39.

Taylor, L. R., 1973. Monitoring changes in the distribution and the abundance of insects. Report Rothamsted Exp. Station 1973, Part 2, 202-239.

Walters, K. F. A., Dixon, A. F. G., 1984. The effect of temperature and wind on the flight activity of cereal aphids. Ann. Appl. Biol. 104, 17-26. 